\section{CONFLICT OF INTEREST}

The authors declare no conflict of interest.

\section{REFERENCES}

Blazer 3rd DG, Kishi Y, Maru DM, Kopetz S, Chun YS, Overman MJ, Fogelman D, Eng C, Chang DZ, Wang H, Zorzi D, Ribero D, Ellis LM, Glover KY, Wolff RA, Curley SA, Abdalla EK, Vauthey JN (2008) Pathologic response to preoperative chemotherapy: a new outcome end point after resection of hepatic colorectal metastases. J Clin Oncol 26: 5344-5351.

Chun YS, Vauthey JN, Boonsirikamchai P, Maru DM, Kopetz S, Palavecino M, Curley SA, Abdalla EK, Kaur H, Charnsangavej C, Loyer EM (2009) Association of computed tomography morphologic criteria with pathologic response and survival in patients treated with bevacizumab for colorectal liver metastases. JAMA 302: 2338-2344.

Klinger M, Tamandl D, Eipeldauer S, Hacker S, Herberger B, Kaczirek K, Dorfmeister M, Gruenberger B, Gruenberger T (2010) Bevacizumab improves pathological response of colorectal cancer liver metastases treated with XELOX/FOLFOX. Ann Surg Oncol 17: 2059-2065.

Li Chang HH, Leeper R, Chan G, Quan D, Driman DK (2012) Infarct-like necrosis: a distinct form of necrosis seen in colorectal carcinoma liver metastases treated with perioperative chemotherapy. Am J Surg Pathol 36: 570-576.
Loupakis F, Schirripa M, Caparello C, Funel N, Pollina L, Vasile E, Cremolini C, Salvatore L, Morvillo M, Antoniotti C, Marmorino F, Masi G, Falcone A (2013) Histopathologic evaluation of liver metastases from colorectal cancer in patients treated with FOLFOXIRI plus bevacizumab. Br J Cancer 108: 2549-2556.

Maru D, Kopetz S, Boonsirikamchai P, Agarwal A, Chun YS, Wang H, Abdalla EK, Kaur H, Charnsangavej C, Vauthey JN, Loyer EM (2010) Tumour thickness at the tumour-normal interface: a novel pathologic indicator of chemotherapy response in hepatic colorectal metastases. Am J Surg Pathol 34: 1287-1294.

Rubbia-Brandt L, Giostra E, Brezault C, Roth AD, Andres A, Audard V, Sartoretti P, Dousset B, Majno PE, Soubrane O, Chaussade S, Mentha G Terris B (2007) Importance of histological tumour response assessment in predicting the outcome in patients with colorectal liver metastases treated with neo-adjuvant chemotherapy followed by liver surgery. Ann Oncol 18: 299-304.

Wicherts DA, de Haas RJ, Sebagh M, Saenz Corrales E, Gorden DL, Levi F, Paule B, Azoulay D, Castaing D, Adam R (2011) Impact of bevacizumab on functional recovery and histology of the liver after resection of colorectal metastases. Br J Surg 98: 399-407.

(1) (2) (2) This work is licensed under the Creative Commons Attribution-NonCommercial-Share Alike 3.0 Unported License. To view a copy of this license, visit http://creativecommons. org/licenses/by-nc-sa/3.0/

\title{
Reply: Comment on 'Histopathologic evaluation of liver metastases from colorectal cancer patients treated with FOLFOXIRI plus bevacizumab"
}

\author{
M Schirripa ${ }^{1}$, F Loupakis ${ }^{\star}, 1$, L Pollina ${ }^{2}$, C Cremolini ${ }^{1}$, G Pasquini ${ }^{1}$ and A Falcone ${ }^{1}$ \\ ${ }^{1}$ Unit of MedicalOncology 2, Azienda Ospedaliero-Universitaria Pisana, via Roma 57, 56126 Pisa, Italy and ${ }^{2}$ Unit of Pathology 2, \\ Department of Laboratory Medicine and Molecular Diagnosis, Azienda Ospedaliero-Universitaria Pisana, via Roma 57, 56126 Pisa, Italy
}

Sir,

We would like to thank Bibeau et al (2013) for their constructive comment on our article. We acknowledge that the question raised is of crucial interest and, as the evaluation of infarct-like necrosis (ILN) was not planned in our analyses, we went back to our samples in order to investigate it.
We adopted the definition of ILN previously proposed (Chang et al, 2012) and we found 24 (37\%) out of 65 patients showing ILN, characterised by large confluent areas of eosinophilic cytoplasmic remnants, located centrally within a lesion and surrounded by a rim of fibrosis with foamy macrophages (Figure 1). Infarct-like necrosis was observed in $1(5 \%)$ out of 28 patients in the control 

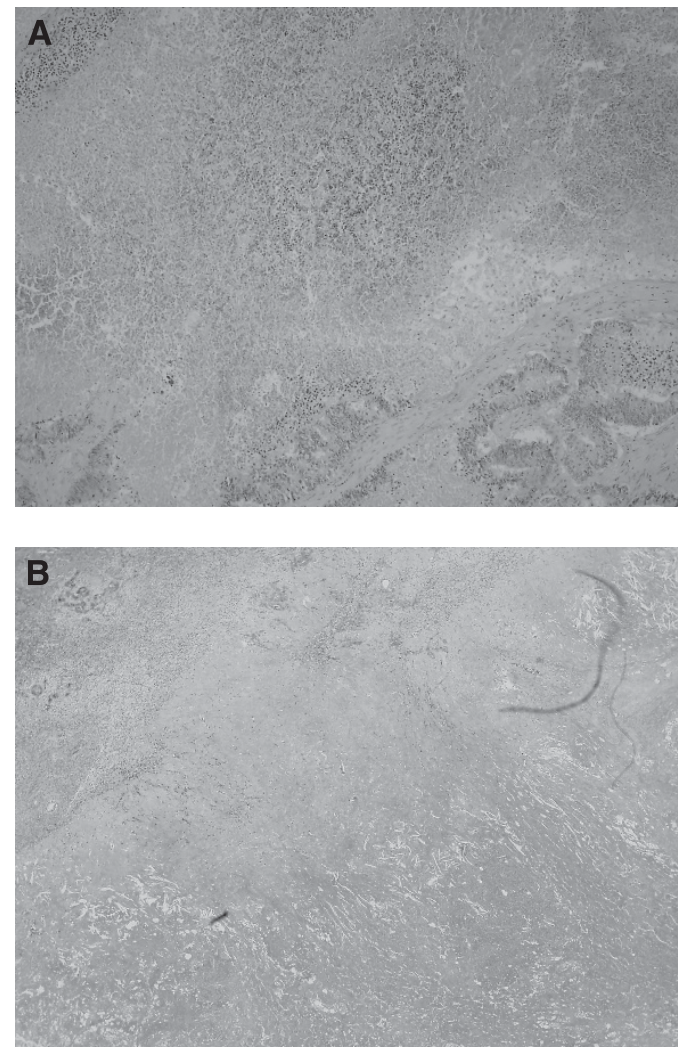

Figure 1. Examples of usual necrosis (A) and infarct-like necrosis (B).

group, in $4(27 \%)$ out of 18 in the chemotherapy group and in 19 (83\%) out of 24 in the bevacizumab group $(P<0.0001)$. The 'bevacizumab-related effect' previously described was also confirmed in our study (bevacizumab group $v s$ chemotherapy group, $P=0.0009$; Table 1).

In our samples, patients showing a pathologic response according to the classification proposed by Blazer et al (2008) were more likely to present ILN in comparison to patients showing no pathologic response: ILN was present in $71 \%$ of patients showing tumour regression grade (TRG) $1-2-3$ vs $29 \%$ of patients with TRG $4-5(P=0.0008)$. These data strengthen the observation that ILN should be regarded as a particular feature of pathologic response induced by preoperative treatments.

Exploratory outcome analyses showed no differences in terms of progression-free survival according to the presence of ILN both among all treated patients $(\mathrm{HR}=0.59,95 \% \mathrm{CI}: 0.25-1.36 ; P=0.21)$
Table 1. Frequency of infarct-like necrosis in colorectal liver metastases according to treatment

\begin{tabular}{|l|c|c|}
\hline & \multicolumn{1}{|c|}{$\begin{array}{c}\text { Bevacizumab } \\
\text { group, } \mathbf{N}=\mathbf{2 4}\end{array}$} & $\begin{array}{l}\text { Chemotherapy } \\
\text { group, } \mathbf{N}=18\end{array}$ \\
\hline Presence of ILN & $19(83 \%)^{\mathbf{a}}$ & $4(27 \%)^{\mathbf{b}}$ \\
\hline Lack of ILN & $4(17 \%)^{\mathbf{a}}$ & $11(73 \%)^{\mathbf{b}}$ \\
\hline $\begin{array}{l}\text { Abbreviation: ILN }=\text { infarct-like necrosis. } \\
\text { a One patient not evaluable. } \\
\text { b }\end{array}$ & \\
\hline
\end{tabular}

and in the bevacizumab group $(\mathrm{HR}=0.42,95 \% \mathrm{CI}: 0.06-1.77$; $P=0.19)$. Nevertheless, such analyses in our cohort are affected by the relatively small sample size.

In conclusion, we definitely agree with the proposal from Bibeau et al (2013) to include the evaluation of ILN in future studies assessing pathologic response of colorectal liver metastases to preoperative treatments.

\section{CONFLICT OF INTEREST}

The authors declare no conflict of interest.

\section{REFERENCES}

Bibeau F, Gil H, Castan F, Boissière-Michot F (2013) Comment on 'Histopathologic evaluation of liver metastases from colorectal cancer in patients treated with FOLFOXIRI plus bevacizumab'. $\mathrm{Br}$ J Cancer 109(12): 3129-3130.

Blazer 3rd DG, Kishi Y, Maru DM, Kopetz S, Chun YS, Overman MJ, Fogelman D, Eng C, Chang DZ, Wang H, Zorzi D, Ribero D, Ellis LM, Glover KY, Wolff RA, Curley SA, Abdalla EK, Vauthey JN (2008) Pathologic response to preoperative chemotherapy: a new outcome end point after resection of hepatic colorectal metastases. J Clin Oncol 26: 5344-5351.

Chang HH, Leeper WR, Chan G, Quan D, Driman DK (2012) Infarct-like necrosis: a distinct form of necrosis seen in colorectal carcinoma liver metastases treated with perioperative chemotherapy. Am J Surg Pathol 36: $570-576$.

(c) (2) (2) This work is licensed under the Creative Commons (c) ${ }_{\mathrm{BY}} \mathrm{NC}$ SA Attribution-NonCommercial-Share Alike 3.0 Unported License. To view a copy of this license, visit http://creativecommons. org/licenses/by-nc-sa/3.0/ 